\title{
A Comparative Study of Uygur and English Translation Methods in "The Story of the Stone"*
}

\author{
Zainahan Abuduo \\ School of Uyghur Language and Culture \\ Northwest Minzu University \\ Lanzhou, China \\ School of Humanities \\ Kashgar University \\ Kashgar, China
}

\author{
Abuduwaili Keremu \\ School of Uyghur Language and Culture \\ Northwest Minzu University \\ Lanzhou, China
}

\begin{abstract}
In this paper, the author analyzes the translation methods of words, phrases, sentences, poetry and texts in Uyghur translation and the English translation of "The Story of the Stone" which are translated by David Hawkes, Yang Xianyi and Dai Naidie. And the comparative result is the Uyghur translation of "The Story of the Stone" uses many communication translation methods, especially the poetry, songs and other rhythm texts which is closer to the overall rules of Hawkes' communicative translation. Yang's translation often uses the methods of semantic translation and retains the contents of cultural significance, the translator's language background played a greater role in the translation. The translation level of Uyghur's full translation of "The Story of the Stone" is not inferior to Hawkes' translation level.
\end{abstract}

Keywords-"The Story of the Stone"; uighur translation; English translation; comparative study of methods

\section{INTRODUCTION}

The contact of "The Story of the Stone" with ethnic minorities in Xinjiang was in the early 1970s, it was translated by Abdou Karim Hoja (1928-1988), Yimin Tulson (born in 1925), Rehman Mamud (born in 1945), Rehmutulla Jary
(1926). -1999) and Hao Guanzhong (1935-1994). We could tell the differences and similarities with the Uighur Full Translation and English translation of "The Story of the Stone" mainly is the translation versions of David Hawkes and Yang Xianyi, Dai Naidie.

\section{THE COMPARISON OF NAME TRANSLATION IN “THE STORY OF THE STONE"}

The title of Uygur's translation of "The Story of the Stone" is translated into "qizil rawaqtiki šx". Rawaq- means "building", in Uyghur translates the name of the book according to its literal meaning. In fact, the Uighur "red" word "qizil" has "false, angry, poor" and other associative meanings, such as "qizil köz" (crook, deception), "qep - qizil yalg an" (completely false), qezir ip qalmaq (dispute), "qizil paçaq" (poor), and of course at Uighur weddings red silk will be tied on horse's head and in front of the car, and a red cloth was attached to the door when a child was born.[1] Several evolutionary processes of name change mentioned in the first chapter of "The Story of the Stone", in translations, different language translators do not have the same translations.

TABLE I. A DISCUSSION ON THE TITLE TRANSLATION

\begin{tabular}{|c|c|c|c|c|c|}
\hline & 石头记 & 情僧录 & 风月宝鉴 & 金陵十二钗 & Chapter 5 of 红楼梦 \\
\hline Uygur translation & $\begin{array}{l}\text { tašni } \text { riwayti } \\
\text { [2] }\end{array}$ & $\begin{array}{l}\text { ašqni xatirsi } \\
\text { [3] }\end{array}$ & $\begin{array}{l}\text { Aynäi } \\
\text { jahannäma [4] }\end{array}$ & $\begin{array}{ll}\text { Jinlindiki } & \text { onikki } \\
\text { sahibjamal } & \\
\end{array}$ & qizil rawaqtikiçšs [5] \\
\hline $\begin{array}{l}\text { Hawkes } \\
\text { translation }\end{array}$ & $\begin{array}{l}\text { The Story of } \\
\text { the Stone }\end{array}$ & $\begin{array}{l}\text { The Taleof Brother } \\
\text { Amor }\end{array}$ & $\begin{array}{l}\text { A Mirror for } \mathrm{R} \\
\text { omantic }\end{array}$ & $\begin{array}{l}\text { The Twelve Beautiesof } \\
\text { jinling. }\end{array}$ & $\begin{array}{l}\text { A Dream of Golden } \\
\text { Days. }\end{array}$ \\
\hline $\begin{array}{l}\text { Yang Xianyi } \\
\text { translation }\end{array}$ & $\begin{array}{l}\text { The Tale of the } \\
\text { stone. }\end{array}$ & $\begin{array}{l}\text { Record ofthe Passio } \\
\text { nate Monk. }\end{array}$ & $\begin{array}{l}\text { PreciousMirror } \\
\text { of Love }\end{array}$ & $\begin{array}{l}\text { The Twelve Beautiesof } \\
\text { jinling }\end{array}$ & $\begin{array}{l}\text { A Dreamof Red } \\
\text { Mansions }^{\text {s }}\end{array}$ \\
\hline
\end{tabular}

The following is a discussion on the title translation of Yang Xianyi's translation, Hawkes' translation and Uyghur's translation.

With regard to the method of translation of “石头记”, the Uyghur and Yang's translations are close to each other in

*This article is an intermittent result of "A Study on Uyghur Folk Oral Poetics"[15BZW196] which funded by the 2015 National Social Science Fund Western Project, and a stage achievement of "a research of Uyghur Language and Literature Research Team" [1001860538/001]by Chinese Language and Literature First Class Key Project of 2017Central Universities Basic Business Fund. terms of understanding. They both translated "记” as "tale", Uighur translations "riwayt" and English Tale all mean legendary here. For Hawkes, his translation is "Story". In fact,

the legend has stronger reality than the story, so translation of tale may be closer to the author's original intention.

The “僧” in the “情僧录” often refers to a ruthless monk. " 情僧" is a combination of "情" and "僧". It is a combination of sentimentality and ruthlessness. It is synonymous with true Buddha. [6] In the end of "The story of the stone" Jia Baoyu 
gives up everything and become a monk. Therefore, the translation of "情僧" is more important. Uighur translation does not translate the meaning of "僧", "ašiq" means who is whose lover in Uighur. In Uyghur the monk uses "rayip" to express, here the translator uses the missing translation method to solve the vacant word problem. Hawkes' translation is the same as Uighur translation, and Yang's translation retains the meaning of the original culture.

The significance of “风月宝鉴” is to “admonish people not to indulge in passions and desires, passions are poisons, and desires are harm --- "The obscene word can't be committed, but the love word is untouchable either, only scared moral is the treasure”. [7]“风月宝鉴” is difficult to translate into any language, Uygur translation "Aynäi jahannäma” and Hawkes" translation "A Mirror for Romantic" all use the communication translation method.

The Uighur translation, Hawkes translation, and Yang's translation of “金陵十二铅” all use the literal translation method.

\section{THE COMPARISON OF WORD TRANSLATION}

Example: 贾政哪里肯听, 说道: “你们问问他于的勾当可饶不可 饶! 素日皆! 你们这些人把他酿坏了, 到这步田地还来解劝。明日酿到他 斌君杀父, 你们才不劝不成! [8]”

The word "corrupt" is well-intentioned here and translated into "yan besip (protect) [9] (asylum) in Uighur. Yang translated it into "spoil" and Hawkes translated into "corrupt". Uighur's translation method is almost the same as Yang's translation method. It avoids the original meaning of brewing. Hawkes' translation is more scrutinized, because before the "encouragement" is used by translator for the sentence so that to be close to Jia Zheng's identity tone. The translation of Yang and Uighur is slightly inferior to Hawkes' translation.

Example: 刘姥姥便不敢过, 且掸了掸衣服, 又教了板儿几向话, 然后蹭到角门前。[10]

In the sentence, "蹭" is translated into asta gina in the Uighur translation[11] (According to the translation, it is interpreted as a cautious and slowly walking), it expressed the real meaning of “蹭”. Hawkes' translation is "Waddled up to" and Yang's translation is "forward". As these three methods of translation all translate the real meaning so the methods are about equal.

For the sentence of “宝玉只得前去, 一步挪不了三寸, 蹭到这边 来”[12], Uighur translated into "aran käldi [13] (finally come) with an adjective instead of the word "蹭 ", Hawkes" translation is "Advanced him only a few inches upon his way". Yang's translation is "dragging step". "蹭" is a rather special word in Chinese, and translators all use the standard vocabulary of the target language to replace it. They are all naturalized translation methods.

\section{TRANSLATION OF HOMOPHONIC WORDS}

\section{A. Phonological Spice}

Example: 凤姐笑道: “我又不会作什么湿的干的, 要我吃东西去 不成”

Example: 探春道: “你虽不会作, 也不要你作。你只监察着我们 里头有偷安急惰的, 该怎么样罚他就是了。” [14] (Chapter 45)

The “湿的千的” in Uygur translates is: “šeir peir" [15](回 译: “诗歌什么的”) Here: "湿" in "湿的干的" is the homonym of "诗", in Uighur it is translated with the original meaning of "诗 " - "šeir", and added meaningless and rhyming word - "peir", and although lost homophonic words, the taste of original text and the tone and personality of Fengjie in the original text are expressed. In English translation, Hawkes translates into "about poetry mietry", Yang translated into "no hand at versifying". Both Hawkes and Uygur translated the homonym “湿” in “湿的干的”. The Uighur "peir" and the "mietry" in English have no physical meaning. They only have the effect of rhyming harmony, and can express Wang Xifeng's uninterested tone in poetry. The Uygur translation also achieves this effect and is not inferior to the translation method of Hawkes' translation.

\section{B. Semantic Pun}

Example: 因此仰望杏子不舍。又想起邢岫烟已择了夫婿一事, 虽 说是男女大事, 不可不行, 但未免又少了一个好女儿。不过两年, 便也 要"绿叶成荫子满枝"了。再过几日, 这杏树子落枝空, 再几年, 岫烟未 免乌发如银, 红颜似槁了, 因此不免伤心, 只管对杏流泪叹息。[16]

The "子" in “绿叶成荫子满枝” has semantic pun likened to "children" in the passage. The original meaning "fruit" is translated in Uighur as: "säya tašlap mevä qaplapdu šaxni" [17], the entire translation sentence is consistent with the original meaning, “子” is also translated as the original meaning fruit, Yang's translation uses the two words "Children, fruits" at the same time, Hawkes' translation is "Married woman with a brood of children". Both of them translated the metaphor meaning of the "子", but Uighur did not translate it out. The Uighur "mevä" means fruit and it does not have obvious meaning of childbirth. So in translation method they are exactly the same.

\section{The Translation of SENTENCE}

Translation of skip sentence-style, skip sentence-style, interrupting a language due to a special context, such as semantic subtlety, a sharp turn of the mind, prominent things, etc., sometimes deliberately interrupting sentences, causing incomplete semantics, or incomplete sentence components, it is an abnormal form of language..

Example: 刚擦着, 猛林黛玉直声叫道: 宝玉, 宝玉，你好……, 说到 “好” 字, 便浑身冷汗, 不作声了。

This sentence is Lin Daiyu's last sentence before her death. It has profound significance so it is difficult to translate. In Uygur translation, “你好......" is "siz nemidegn bagri..." which means: “您的心肠怎如此” ... Here, the translator added the "心 肠" into it, so that the original blank point was reduced. Yang translated with a word "how". Yang's translation here is 
closer to the original acceptance blank points and the translation methods of Hawkes and Uighur are close.

\section{The Translation of Classical Chinese}

Example:邢夫人苦留吃过晚饭去, 黛玉笑回道: “舅母爱惜赐 饭, 原不应辞, 只是还要过去拜见二舅舅, 恐领了赐去不恭, 异日再 领, 未为不可。望舅母容谅”[18]

The translation of several words in this sentence is very important, "赐饭", "不恭", "容谅" and "异日". These words are in the form of classical Chinese. Uygur translations are "g iza hazir liš" [19],"bihörmät" Uyghur translation also uses the classical elegant words, missing translation of "异日", use "keyn (later)" -instead of "异日", the translation of “原不应辞” is also not properly translated, it translated as "äsla to $\gamma \mathrm{ra}$ äms." This sentence is too close to modern Uyghur, but in this sentence the author has arranged this classic Chinese for Lin Daiyu with ulterior motives. The expression of Lin Daiyu's linguistic form this sentence could express her cultural accomplishment. The translation of Yang in this sentence is also more vernacular. In Hawkes' translation, he simply "translates Lin Daiyu's speech into a third-person report".[20] Although translations are all not appropriate, since translation of Chinese classical language is a very difficult field, the above translators have already made their best efforts.

\section{TRANSLATION OF SONGS}

"好了歌" is called "the outline" of "The Story of the Stone"[21]. "This song “好了歌' expressed the singer's negative attitude towards life”. [22] “世人都晓神仙好” in Uygur translation is "xälqi-aläm däydu birdäk pärštä obdan”[23]. We only discuss the translation of the gods, the Uygur translation of the word is "pärštä" which is the "神仙" in Taoism that focuses on the desire for nothing, in the Uygur translation, in order to rhyme with the hä, läm, dä, däk in the first sentence, it is translated into "pärštä" angel, Uyghur pärštä has different meaning with immortal, Uighur "äwliya" also means immortal, but why "äwliya" is not chosen is because the meaning of this word is: People who can predict the future and affect People's life and living. According to the translation of Uyghur, there is a closer word "zayit", in Uyghur language "zayit" is a person who has been specially guarding the grave, but also lives away from the crowd and lives alone. The translator wants to make Uygur readers to enjoy the beauty of poetry rhythm as same as the original poetry, so they use the word "pärštä" (angle) to convert, it can also be said that for the form beauty of poetry, the "meaning" was abandoned on this word, Hawkes translated into "salvation", "pärštä" angel, the translation method is needed for the form, but similar with Hawkes' translation. In terms of Uygur's translation structure, the translation is also 16 sentences with the same translation format. The translator also translates the long and short sentence features of the original poem. The longest sentence in the translation includes 7 words, the shortest sentence consists of five words. The Uygur translation has very clear and neat form and the translation is quite catchy and very musical, which is almost the same as the aesthetic effect of Hawkes' translation.

\section{TRANSLATION OF PHRASES}

"奴去也, 莫牵连" [24], kättim mana, rišti ๆni mändin uz biraq [25]. The "奴" in this sentence is not translated. The reason why the translator does not translate is to regulate the form of the word's temperament so they do not translate the word "奴". Hawkes' translation is "Now I am gone", and Uighur translation is kättim mana (I go), the translation methods are the same. Yang's translation uses semantic translation to retain the meaning of the original text, and Hawkes and Uyghur translation missed the translation of “奴”, they use communication translation method to get close to readers.

\section{THE TRANSLATION OF POETRY} Stone.

The first poem of the first volume of The Story of the

$$
\begin{aligned}
& \text { 满纸荒唐言, } \\
& \text { 一把辛酸泪! } \\
& \text { 都云作者痴, } \\
& \text { 谁解其中味? }
\end{aligned}
$$

David Haw kes(Cao \&Gao1973 :51)

Pag es full of idle w ords

Penned w ith ho $t$ and bit ter tears :

All men call the autho $\mathrm{r}$ foo 1 ;

No ne his secret messages hears .

It is translated by Yang Xianyi, Dai Naidie(1999:11) as:

Pages full of fantastic talk

Penned w ith bit ter tears ;

All men call the author mad,

None his messages hears .

The full Uygur Translation of The Story of the Stone (1974:8) :

Tolsa gär äpsanigä qäz beti,

Siqdi misralarga aciq köz yeg i !

kag ki,apturni hamaqät därmidi,

tämini tetip üniๆ bilsä kig.[26]

In the first sentence, Hawkes, Yang Xianyi, and Dai Naidie have all translated "荒唐言" into "idle words, fantastic talk", Uighur translation uses "äpsanä (myth)" as an absurd metaphor in some Uighur mythology. The use of this word is better than the direct translation method that Howkes and Yang use, if we use Uygur word to make direct translation then it will weaken the form beauty of poetry, in rhyme Uighur translated beti, yeg i, därmidi, kig, of which rhyme feet is " $\mathrm{i}$ ", in the form it is very rhyme, from which we can see the profound poetry knowledge of the translator, the translation of poetry is like original written by Uighur. The 
reader has the same feeling of enjoyment as the original poetry.

\section{CONCLUSION}

According to Newmark's translation theory, the faithful translation of source language according to the literal meaning is referred as semantic translation, and the free translation of target language in line with language code is called the communication translation. The Uygur translation in the above analysis, used the communication translation method in many words, phrases, and sentences, which is closer to Hawkes' general rules of translation. Yang's translation used more of the methods of semantic translation. Hawkes' native language is English, Uighur translator's native language is Uighur (Uygur trained in Uygur language schools since childhood, so the translator's Uighur language is better than Chinese). The two translators with the same language background are closer, and the translator's language background is very obvious here. The level of Uygur translation in "The Story of the Stone" can be said to have reached the same level as Hawkes' translation.

\section{REFERENCES}

[1] "Frontier", "The Metaphorized Cognition of Uygur Basic Color Words" Shadia Ibrahim, 22nd Issue, 2013; 《前沿》“维吾尔语基本颜色词的 隐喻化认知”夏迪娅·伊布拉音, 2013 年第 22 期;

[2] "The story of the stone" Uyghur translation, Xinjiang People's Publishing Company, P. 8 in book 1, 2ndedition in November 2012 ; 《红楼梦》维吾尔文, 新疆人民出版社, 2012 年 11 月第 2 版, 第 一册第 8 页;

[3] "The story of the stone" Uyghur translation, Xinjiang People's Publishing Company, P. 8 in book 1, 2ndedition in November 2012 ; 《红楼梦》维吾尔文, 新疆人民出版社, 2012 年 11 月第 2 版, 第 一册第 8 页;

[4] "The story of the stone" Uyghur translation, Xinjiang People's Publishing Company, P. 8 in book 1, 2ndedition in November 2012 ; 《红楼梦》维吾尔文, 新疆人民出版社, 2012 年 11 月, 第 2 版第 一册第 8 页;

[5] "The story of the stone" Uyghur translation, Xinjiang People's Publishing Company, P. 124 in book 1, 2ndedition in November 2012 ; 《红楼梦》维吾尔文, 新疆人民出版社, 2012 年 11 月第 2 版, 第 一册第 124 页;

[6] Liao Kebin, Liu Minhong "New Explanations on the Connotations of the Five Titles of 'The story of the stone'”, Masterpiece Appreciation, 2016, Issue 17 廖可斌、刘民红《红楼梦》五个书名内涵新论 名作 欣赏 2016 年, 17 期

[7] Liao Kebin, Liu Minhong "New Explanations on the Connotations of the Five Titles of "The story of the stone'", Masterpiece Appreciation, 2016, Issue 17 廖可斌、刘民红《红楼梦》五个书名内涵新论 名作 欣赏 2016 年, 17 期

[8] "The story of the stone" First Volume, People's Literature Publishing Company, Cao Xueqin, Gao E, Edition in 1982, P.444. 《红楼梦》上 册, 人民文学出版社, 曹雪芹, 高鹗 1982 年版, 444 页

[9] "The story of the stone" Uyghur translation, Xinjiang People's Publishing Company, P. 50 in book 2, 2ndedition in November 2012 ; 《红楼梦》维吾尔文, 2012 年新疆人民出版社 11 月第 2 版, 第二 册 50 页

[10] "The story of the stone" First Volume, People's Literature Publishing Company, Cao Xueqin, Gao E, Edition in 1982, P.93. 《红楼梦》上 册, 人民文学出版社, 曹雪芹, 高鹗 1982 年版 93 页

[11] "The story of the stone"Uyghur translation, Xinjiang People's Publishing Company, P. 145 in book 3, 2ndedition in November 2012 ;
《红楼梦》维吾尔文, 新疆人民出版社, 2012 年 11 月第 2 版第三 册 145 页

[12] "The story of the stone" First Volume, People's Literature Publishing Company, Cao Xueqin, Gao E, Edition in 1982, P.309 《红楼梦》上 册, 人民文学出版社, 曹雪芹, 高鹗 1982 年版, 309 页

[13] "The story of the stone" Uyghur translation, Xinjiang People's Publishing Company, P. 516 in book 1, 2ndedition in November 2012 ; 《红楼梦》维吾尔文, 年新疆人民出版社, 2012 年 11 月第 2 版第 一册 516 页

[14] "The story of the stone" First Volume, People's Literature Publishing Company, Cao Xueqin, Gao E, Edition in 1982, P.599《红楼梦》上 册, 人民文学出版社。曹雪芹, 高鹗 1982 年, 599 页

[15] "The story of the stone" Uyg hur translation, Xinjiang People's Publishing Company, P. 339 in book 2, 2ndedition in November 2012 ; 《红楼梦》维吾尔文, 2012 年新疆人民出版社 11 月第 2 版, 第二 册 339 页

[16] "The story of the stone" First Volume, People's Literature Publishing Company, Cao Xueqin, Gao E, Edition in 1982, P.800《红楼梦》上 册, 人民文学出版社。曹雪芹, 高鹗 1982 年, 800 页

[17] "The story of the stone" Uyghur translation, Xinjiang People's Publishing Company, P. 701 in book 2, 2ndedition in November 2012 ; 《红楼梦》维吾尔文, 2012 年新疆人民出版社 11 月第 2 版, 第二 册 701 页

[18] "The story of the stone" First Volume, People's Literature Publishing Company, Cao Xueqin, Gao E, Edition in 1982, P.42《红楼梦》上 册, 人民文学出版社, 曹雪芹, 高鹗 1982 年版, 42 页

[19] "The story of the stone" Uyghur translation, Xinjiang People's Publishing Company, P. 65 in book 1, 2ndedition in November 2012 ; 《红楼梦》维吾尔文, 2012 年新疆人民出版社, 第一册 65 页

[20] Feng Qinghua, "Research on the Translation Art of 'The story of the stone",, Shanghai Foreign Language Education Press. September 2006 《红楼梦》翻译艺术研究, 冯庆华, 上海外语教育出版社出版。 2006 年 9 月。

[21] [1] Jiang Qihuang, "The Seven English Translations of 'Hao liao ge", Chinese Translation [J], 1996 (4). [1]姜其煌, 《好了歌》的七种英译. 中国翻译[J], 1996(4).

[22] [2] Dang Zhengsheng, "A Comparative Study of the English Translation of "The story of the stone"'[M]. Beijing: Peking University Press, 2012,P. 14[2]党争胜, 《红楼梦》英译艺术比较研究[M]. 北京: 北 京大学出版社, 2012 年, 14 页

[23] "The story of the stone"Uyghur translation, Xinjiang People's Publishing Company, P. 25 in book 1, 2ndedition in November 2012 ; 《红楼梦》维吾尔文, 2012 年新疆人民出版社 11 月第 2 版, 第一 册 25 页

[24] "The story of the stone" First Volume, People's Literature Publishing Company, Cao Xueqin, Gao E, Edition in 1982, P.83《红楼梦》上 册, 人民文学出版社, 曹雪芹, 高鹗 1982 年版, 83 页

[25] "The story of the stone" Uyghur translation, Xinjiang People's Publishing Company, P. 127 in book 1, 2ndedition in November 2012 ; 《红楼梦》维吾尔文, 2012 年新疆人民出版社 11 月第 2 版, 第一 册 127 页

[26] "The story of the stone" Uyghur translation, Xinjiang People's Publishing Company, P. 8 in book 1, 2ndedition in November 2012 ; 《红楼梦》维吾尔文, 2012 年新疆人民出版社 11 月, 第 2 版, 第 一册 8 页 